\section{Animal Tissue Compost as a Potential Substrate Amendment for Production of Four Annual Floriculture Crops}

\author{
Kristin L. Getter ${ }^{1,3}$ and Dale W. Rozeboom ${ }^{2}$
}

AdDitional INDEX wORDs. geranium, Pelargonium $\times$ bortorum, marigold, Tagetes evecta, pansy, Viola $\times$ wittrockiana, petunia, Petunia $\times$ bybrida, media amendments, peat substitute

SUMMARY. The objectives of this study were to determine the effectiveness of using animal tissue compost (ATC) as a substrate amendment for ornamental plant container production. The compost was produced using soiled sawdust bedding mixed with assorted animal tissues and actively composted for at least 6 months and cured for 6 to 10 months. Five substrate treatments that consisted of four different ratios of ATC and Canadian sphagnum peatmoss were formulated, all containing $\mathbf{2 0 \%}$ medium grade horticultural perlite. Four species [geranium (Pelargonium $\times$ bortorum 'Maverick Red'), marigold (Tagetes evecta' 'Inca II Yellow'), pansy (Viola $\times$ wittrockiana 'Delta Premium Yellow Blotch'), and petunia (Petunia $\times$ bybrida 'Prostrate Wave Purple Improved')] were evaluated with weekly plant measurements. Geranium and petunia exhibited $100 \%$ survival for all treatments. Marigold and pansy showed $100 \%$ survival for the control treatment (0\% ATC) and the treatment with the smallest amount of ATC (20\% ATC). Treatments for pansy and marigold with more than $40 \%$ ATC exhibited $40 \%$ to $90 \%$ survival. All ATC substrate treatments produced the same number of flowers and buds as the control in geranium, marigold, and petunia, while the treatments containing $20 \%$ to $60 \%$ of ATC for pansy exhibited more flowers and buds than the control. Measurements of $\mathrm{pH}$ and electrical conductivity (EC) varied based on treatment. Based on the species and the ratios of peat, ATC, and perlite tested here, ATC has the potential to be a peat extender in floriculture substrates when used in ratios of $20 \%$ or less.

$\mathrm{P}$ eat is a commonly used substrate component in floriculture production (Nelson, 2003). Recently, there has been interest in reducing peat use in horticulture for a variety of reasons, including environmental concerns of peat harvesting (Larcher and Scariot, 2009) and peat scarcity issues during years of excessive precipitation (Jackson and Fonteno, 2013). In addition, the United States imports $69 \%$ of consumed peat from Canada (U.S. Geological Survey, 2014). Rising fuel costs can thus make peat more costly than local substrates due to long distance transportation. For this, and other reasons, recent research has focused on peat alternatives or extenders. Such products have included composted dairy manure (Shober et al., 2010, 2011), composted pig manure (Naddaf et al., 2011), urea formaldehyde resin foam

${ }^{1}$ Department of Horticulture, Michigan State University, 1066 Bogue Street, Room A240-E, East Lansing, MI 48824

${ }^{2}$ Department of Animal Science, Michigan State University, 474 S. Shaw Lane, 2209 Anthony Hall, East Lansing, MI 48824

${ }^{3}$ Corresponding author. E-mail: getterk@msu.edu.
(Nektarios et al., 2011), wood substrates (Gaches et al., 2011; Murphy et al., 2011), coir (Gizas et al., 2012), and crop byproducts (Bilderback et al., 1982; Evans, 2011) among others.

One potential peat extender product that has had little if any research is ATC. In the past two to three decades, the dead animal regulations in most states have been rewritten to allow for the composting of animal tissue; carcasses of routine on-farm dead animals and processing byproducts from animal processing businesses. Composting is the biological decomposition of animal tissues under controlled or managed conditions to a condition where storage, handling, and use as a soil amendment is achieved in a safe, aesthetically acceptable, and environmentally sound manner. Animal tissue composting may be effectively and economically done in several different systems (Fulhage, 1994; Keener et al., 2000; Murphy and Handwerker, 1988; Rozeboom et al., 1997; Stanford et al., 2007).

Animal tissue compost has historically been used as a soil amendment or fertilizer on cropland. Not all states require that ATC be fully cured before land application. Generally, it must be composted long enough to be free of any soft tissue. Visible pieces of bone may persist. The potential for other uses for ATC, including the use in container mixes for flowering plants, has received little exploration. To be used in floriculture, the protocols for composting animal tissue would need to provide compost characteristics that will enhance the sale of potted flowering plants. Processing methods need to be developed and studied as to what methods produce the best rooting medium.

Using ATC as an ornamental substrate amendment may be a very good solution for both of these industries. Animal production would have a sustainable system with which to manage normal mortality and byproduct flow, while the floriculture industry may have a source of cheaper substrate amendment to lower costs. This preliminary study looked at the effectiveness of using this compost as a floriculture substrate amendment for ornamental plant container production.

\section{Material and methods}

Animal tissue compost was produced in a composting facility with bins $(10 \times 8 \times 4 \mathrm{ft})$ associated with the Michigan State University (MSU) South Campus Farms, East Lansing. In this system, each new batch is started by layering $\approx 2 / 3 \operatorname{yard}^{3}$ of

\begin{tabular}{llll}
\hline $\begin{array}{l}\text { Units } \\
\begin{array}{l}\text { To convert U.S. to SI, } \\
\text { multiply by }\end{array}\end{array}$ & U.S. unit & SI unit & $\begin{array}{l}\text { To convert SI to U.S., } \\
\text { multiply by }\end{array}$ \\
\hline 0.3048 & $\mathrm{ft}$ & $\mathrm{m}$ & 3.2808 \\
3.7854 & $\mathrm{gal}$ & $\mathrm{L}$ & 0.2642 \\
2.54 & inch $(\mathrm{es})$ & $\mathrm{cm}$ & 0.3937 \\
1 & $\mathrm{mmho} / \mathrm{cm}$ & $\mathrm{mS} \cdot \mathrm{cm}^{-1}$ & 1 \\
1 & $\mathrm{ppm}$ & $\mathrm{mg} \cdot \mathrm{kg}^{-1}$ & 1 \\
1 & $\mathrm{ppm}$ & $\mathrm{mg} \cdot \mathrm{L}^{-1}$ & 1 \\
0.7646 & yard & $\mathrm{m}{ }^{3}$ & 1.3080 \\
$\left({ }^{\circ} \mathrm{F}-32\right) \div 1.8$ & ${ }^{\circ} \mathrm{F}$ & ${ }^{\circ} \mathrm{C}$ & $\left({ }^{\circ} \mathrm{C} \times 1.8\right)+32$ \\
& & &
\end{tabular}


Table 1. Initial media properties of the animal tissue compost (ATC) and the five substrate treatments. The control consisted of $80 \%$ peat with $0 \%$ ATC (80P:0A). The ATC treatments consisted of $0 \%$ peat with $80 \%$ ATC $(0 \mathrm{P}: 80 \mathrm{~A}), 40 \%$ peat with $40 \%$ ATC (40P:40A), $20 \%$ peat with $60 \%$ ATC (20P:60A) and $60 \%$ peat with $20 \%$ ATC (60P:20A). Substrates were mixed on a volume:volume basis.

\begin{tabular}{|c|c|c|c|c|c|c|c|}
\hline \multirow[b]{2}{*}{ Analysis } & \multicolumn{6}{|c|}{ Treatment } & \multirow{2}{*}{$\begin{array}{c}\text { General } \\
\text { recommended ranges }^{\mathrm{z}}\end{array}$} \\
\hline & ATC & 80P:0A & 60P:20A & 40P:40A & 20P:60A & 0P:80A & \\
\hline $\mathrm{pH}$ & 6.2 & 3.9 & 4.5 & 5.2 & 5.4 & 6.0 & $5.0-6.8$ \\
\hline Nitrate $(\mathrm{ppm})^{\mathrm{x}}$ & 980 & 22 & 287 & 615 & 861 & 971 & $40-200$ \\
\hline Phosphorus $(\mathrm{ppm})^{\mathrm{x}}$ & 119.1 & 5.9 & 247.8 & 236.5 & 178.2 & 134.5 & $3-10$ \\
\hline Potassium $(\mathrm{ppm})^{\mathrm{x}}$ & 1,618 & 12 & 504 & 1,037 & 1,381 & 1,596 & $60-250$ \\
\hline Sodium $(\mathrm{ppm})^{\mathrm{x}}$ & 2,627 & 90 & 929 & 1,741 & 2,232 & 2,614 & $0-80$ \\
\hline Sulfur $(\mathrm{ppm})^{\mathrm{x}}$ & 240 & 10 & 82 & 160 & 201 & 225 & $20-200$ \\
\hline Boron $(\mathrm{ppm})^{\mathrm{x}}$ & 0.7 & $<0.1$ & 0.3 & 0.5 & 0.6 & 0.7 & $0.7-2.5$ \\
\hline Iron $(p p m)^{x}$ & 19.4 & 20.3 & 32.8 & 31.6 & 26 & 17.7 & $15-40$ \\
\hline Manganese $(\mathrm{ppm})^{\mathrm{x}}$ & 17 & 0.8 & 12.9 & 16.9 & 17.2 & 16.2 & $5-30$ \\
\hline
\end{tabular}

${ }^{\mathrm{z}}$ General recommended ranges from Dole and Wilkins (2005) and are for generic bedding plants. Values for specific crops may differ.

y Laboratory analysis was performed using the saturated media extract method (A\&L Great Lakes Laboratories, Fort Wayne, IN). Weekly in-house electrical conductivity (EC) measurements were performed using the PourThru method (Whipker et al., 2001 ); $1 \mathrm{mS} \cdot \mathrm{cm}^{-1}=1 \mathrm{mmho} / \mathrm{cm}$.

${ }^{\mathrm{x}} \mathrm{l} \mathrm{ppm}=1 \mathrm{mg} \cdot \mathrm{kg}^{-1}$.

w By loss on ignition at $600{ }^{\circ} \mathrm{C}\left(1112.0^{\circ} \mathrm{F}\right)$.

soiled (with urine, manure, and hay) sawdust bedding in the bottom of the bin. This bedding material is obtained from weekend horse show events at the MSU Pavilion for Agriculture Education. This material typically contains about $45 \%$ moisture, $80 \%$ organic matter, $45 \%$ to $50 \%$ carbon, and $1 \%$ nitrogen. The soiled sawdust bedding is the sole amendment used for animal tissue composting. There is no reuse of old compost and no manures are added. A batch is one bin full, which represents the accumulation of animal tissue for 2 months. Assorted animal tissues from MSU farms (dairy calves, foals, adult and young sheep, adult and young swine, and swine afterbirth) and from the MSU Meats Laboratory (ten 55-gal drums of rumen contents per batch) from bovine and ovine harvest processes are laid on top of the 2 -ft-deep amendment base. Adult sheep and swine are not layered, but other animal tissues may be layered in between amendment layers. The final layer of amendment covers the pile with $\approx 6$ to 12 inches of amendment. Batches are aerated by mechanically lifting and dumping back down into the same bin using a skidsteer loader three times over the course of 4 months until all soft tissues are decomposed. The ATC used in this study was intensively composted for a minimum of 6 months; providing three heat cycles to $130^{\circ} \mathrm{F}$ or greater. Temperatures were taken weekly using a 36-inch-long compost thermometer; $\approx 24$ to 30 inches below the pile surface. After active composting, the ATC was moved to a polebarn nearby, where it was piled and blended with two other batches of ATC and cured for 6 to 10 months more. Accordingly, the first and second batches had cured for 4 and 2 months, respectively, before being thoroughly mixed with the third active batch of ATC. After the third batch was mixed, the entire mixture was cured for a minimum of 6 more months, resulting in the compost of the first and second batches were cured for at least 10 and 8 months, respectively. Maturity of the mixed multiple-batch compost after curing was determined with the Solvita test kit (Woods End Research Laboratory, Mt. Vernon, ME); with ammonia rating being low (5) and carbon dioxide rating being low (7). The overall maturity index was 7 with a laboratory description of the compost: being "well matured, aged compost, cured and few limitations for usage." From the cured ATC compost batches, a 20-gal representative amount of ATC was obtained and moved in 5-gal plastic containers to a laboratory in the Animal
Science Department at MSU. Bones were manually retrieved from these compost samples. Bone and compost components were dried at $100{ }^{\circ} \mathrm{C}$ for $12 \mathrm{~h}$ and after cooling were ground through a Wiley mill. The ground bone and compost components were then blended back together at a $0.66 \%$ ground bone proportion following the reported bone weight as a proportion of final ATC reported by Stanford et al. (2009). A total of 17 gal of dried, ground ATC was available for use as a substrate amendment for ornamental plant container production.

Five substrate treatments that consisted of four different ratios of ATC and Canadian sphagnum peatmoss (Lambert Peat Moss, RivièreOuelle, QC, Canada) were formulated, all containing $20 \%$ medium grade horticultural perlite (P.V.P. Industries, North Bloomfield, $\mathrm{OH})$. The control consisted of $80 \%$ peat with 0\% ATC (80P:0A). The ATC treatments consisted of $60 \%$ peat with $20 \%$ ATC (60P:20A), 40\% peat with $40 \%$ ATC (40P:40A), $20 \%$ peat with 60\% ATC (20P:60A), and 0\% peat with $80 \%$ ATC (0P:80A). Substrates were mixed on a volume:volume basis on 14 Jan. 2014. Samples of each substrate were sent to a laboratory (A\&L Great Lakes Laboratories, Fort 

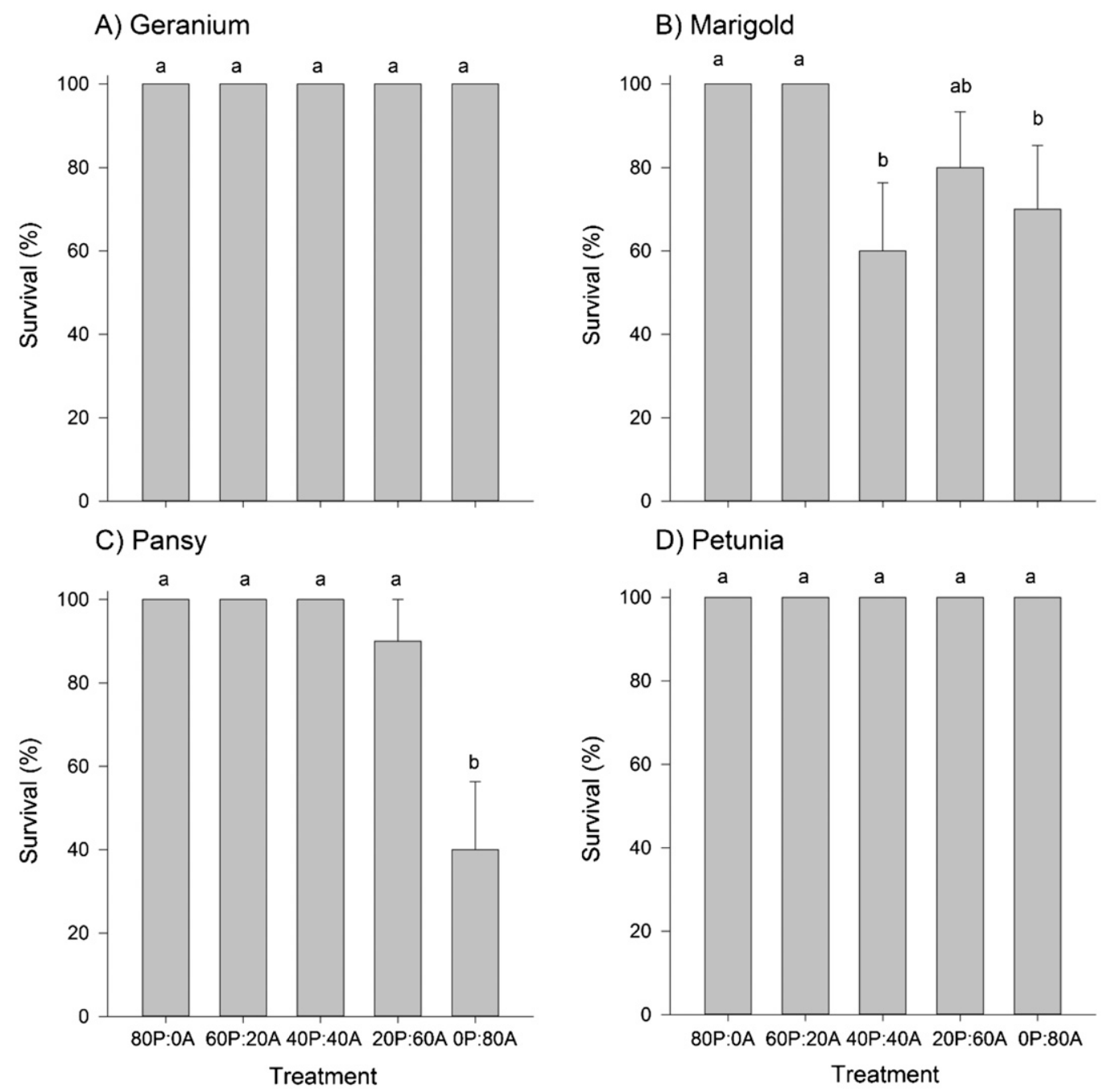

Fig. 1. Survival percentages (with SE) for (A) geranium at $55 \mathrm{~d}$ after transplant (DAT), (B) marigold at $44 \mathrm{DAT}$, (C) pansy at 55 DAT, and (D) petunia at 44 DAT. Bars with the same lower case letters (within a species) are not significantly different according to the Kruskal-Wallis test $(P \leq \mathbf{0 . 0 5})$. Bars with no SE are due to identical measurements across all subjects. Substrate treatments consisted of $80 \%$ peat with $0 \%$ animal tissue compost [ATC (80P:0A)], $60 \%$ peat with $20 \%$ ATC (60P:20A), $40 \%$ peat with $40 \%$ ATC (40P:40A), 20\% peat with 60\% ATC (20P:60A), and 0\% peat with $80 \%$ ATC (0P:80A).

Wayne, IN) for saturated media extract and organic matter analysis.

Seeds of four species (geranium, marigold, pansy, and petunia) were sown in 128-plug trays (except for pansy in 288-plug trays) by a commercial greenhouse (C. Raker \& Sons, Litchfield, MI) in a young plant substrate consisting of peat and perlite. These cultivars were selected by the plug producer based on their commonality and commercial availability. Five to 7 weeks after germination, plugs were received at MSU on 14 Jan. 2014.

Ten plants of each species were assigned to each treatment, resulting in 200 plants in total $(5$ treatments $\times$ 4 species $\times 10$ plants). Plugs were planted into the treatments (in 4 -inch pots) on 15 Jan. 2014. Initial measurements began on 17 Jan. 2014 and continued about once per week thereafter until plants were all in flower (saleable). The greenhouse environment was maintained at a $68^{\circ} \mathrm{F}$ air temperature during the day and 60 ${ }^{\circ} \mathrm{F}$ air temperature at night. The plants were fertilized at each watering with reverse osmosis water containing nutrients [in $\mathrm{mg} \cdot \mathrm{L}^{-1}$ (125 nitrogen, 12 phosphorous, 100 potassium, 65 calcium, 12 magnesium, 1.0 iron and copper, 0.5 manganese and zinc, and 0.1 molybdenum)]. Each pot was individually hand watered as needed.

Weekly plant measurements consisted of several quantitative measures and one qualitative measure. Plant height was measured in centimeters from the top of the soil to the tallest point of the plant. Plant width 1 was measured as the width in centimeters at the widest portion of the plant and plant width 2 was the width perpendicular to plant width 1 in centimeters. A growth index (GI) was then calculated as (plant height + plant width $1+$ plant width 2$) / 3$ to represent the size of the plant. Plant survival was also recorded on a weekly basis with 0 representing a dead plant and 1 representing a living plant (with any green on the plant). Plant health was measured on a scale of 1 to 5 with 1 being a dead plant $(90 \%$ or more death or yellowing), 2 being nearly dead $(75 \%$ to $90 \%$ yellowing or dead spots), 3 being many yellowing or dead spots (50\% to $74 \%), 4$ being minor $(25 \%$ or less $)$ dead spots or yellowing, and 5 being a dense, full canopy with no dieback. Plant health 
A) Geranium

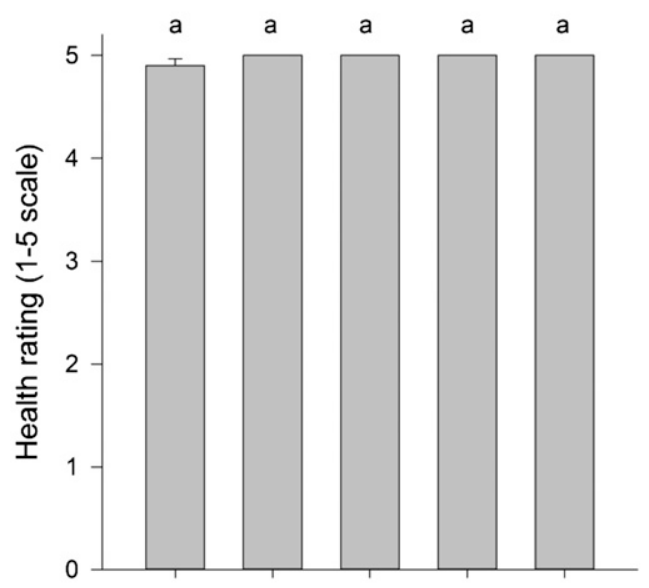

C) Pansy

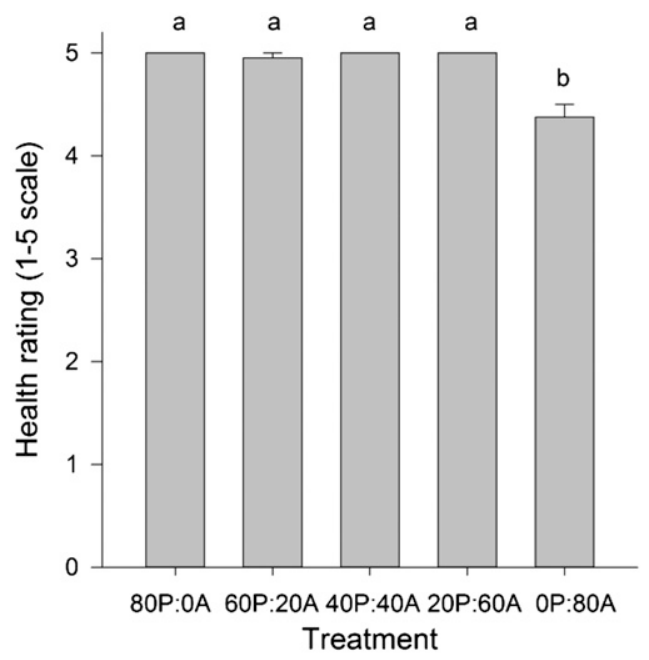

B) Marigold

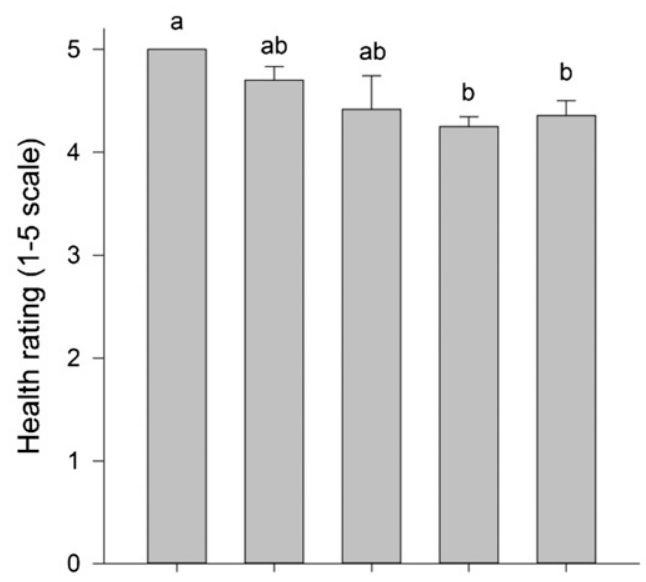

D) Petunia

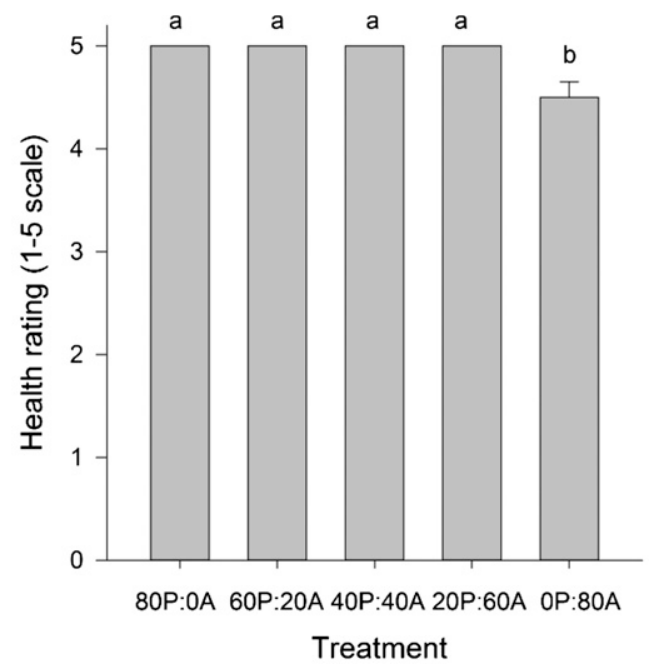

Fig. 2. Health ratings (with SE), excluding dead plants, for (A) geranium at $55 \mathrm{~d}$ after transplant (DAT), (B) marigold at 44 DAT, (C) pansy at 55 DAT, and (D) petunia at 44 DAT. A visual scale of $1-5$ was used with 5 being the healthiest and 1 being dead. Bars with the same lower case letters (within a species) are not significantly different according to paired comparisons (Tukey's honestly significant test with $P=0.05$ as a maximum value of significance). Bars with no SE are due to identical measurements across all subjects. Substrate treatments consisted of 80\% peat with 0\% animal tissue compost [ATC (80P:0A)], $60 \%$ peat with $20 \%$ ATC (60P:20A), $40 \%$ peat with $40 \%$ ATC (40P:40A), $20 \%$ peat with $60 \%$ ATC (20P:60A), and 0\% peat with 80\% ATC (0P:80A).

scores did not include those plants that had died. The number of flowers was also counted as the number of visibly open flowers plus buds with visible color for petunia, pansy, and marigold. For geranium, the number of flowers was the number of flower clusters that have buds with visible color or open flowers. In addition, $\mathrm{pH}$ and $\mathrm{EC}$ of the substrate were measured periodically using the PourThru method (Whipker et al., 2001) throughout the study on three random plants per treatment per species.

Data for each species was analyzed separately as a completely randomized design with five substrate treatments and 10 replications (plants per treatment). Survival data were analyzed using a nonparametric (KruskalWallis) test (PROC NPARIWAY in SAS version 9.3; SAS Institute, Cary, NC). Other growth and substrate measurements were analyzed with PROC GLM and paired comparisons were performed using Tukey's honestly significant test with $P=0.05$ as a maximum value of significance.

\section{Results and discussion}

INITIAL SUbSTRATE PROPERTIES. The initial chemical properties of the substrates differed between the control (80P:0A) and those treatments containing ATC (Table 1). The control (80P:0A) fell within or below the published recommended ranges (Dole and Wilkins, 2005) for all substrate properties measured. For the most part, all other treatments containing ATC were high for many properties, especially EC, nitrate, phosphorus, potassium, and calcium. Of the treatments containing ATC, the treatment with the lowest amount of ATC (60P:20A) had the most acceptable substrate chemical property values.

There can be sizeable variability in the nutrient characteristics of ATCs (Rozeboom and Ross, 2014). 
A) Geranium

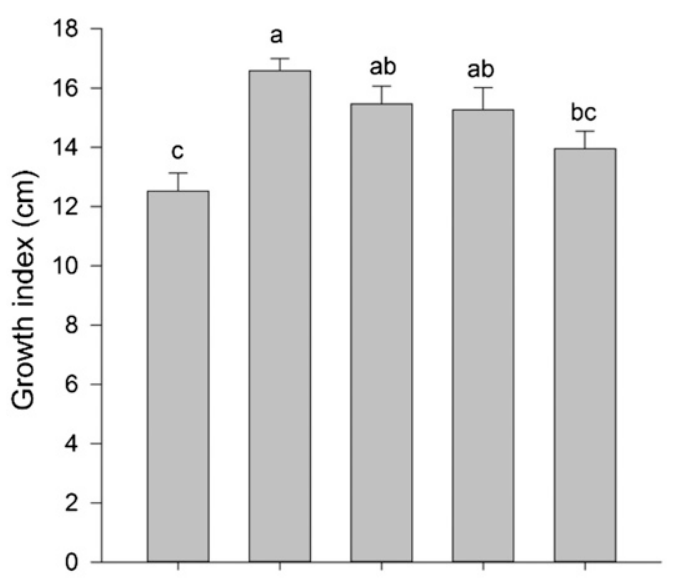

C) Pansy

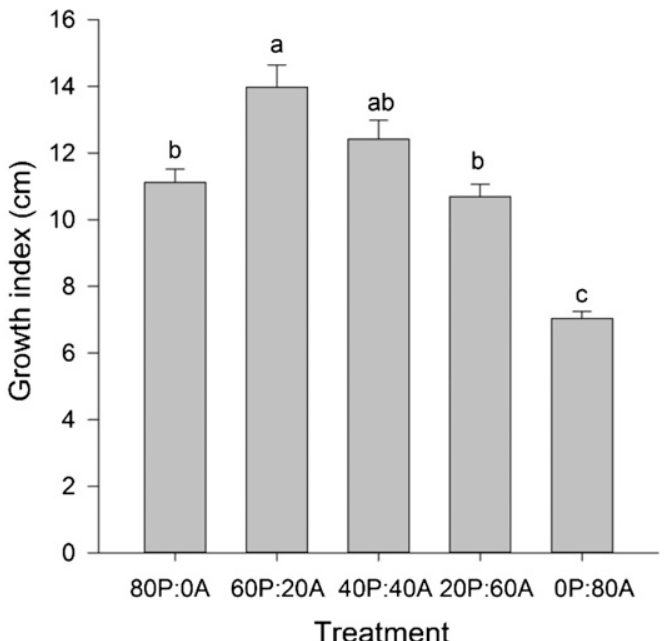

B) Marigold

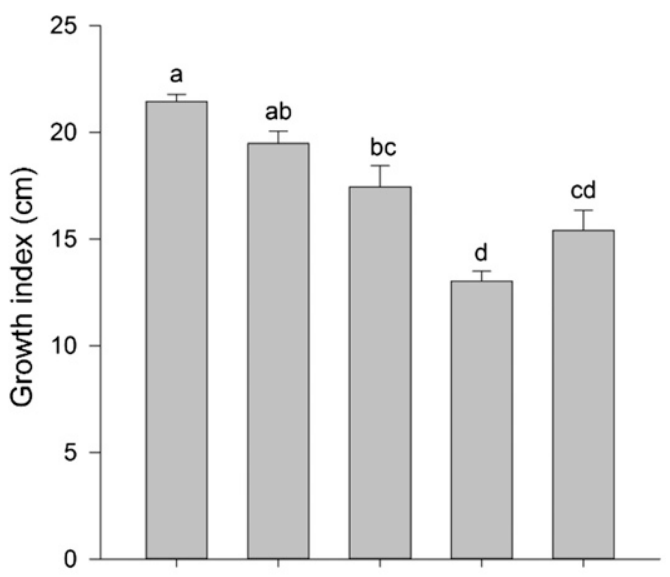

D) Petunia

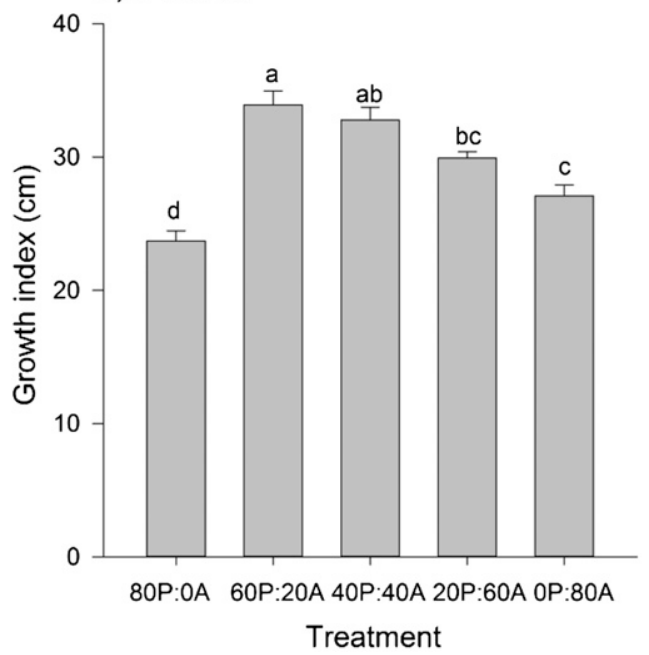

Fig. 3. Growth index [GI (with sE)], excluding dead plants, of (A) geranium at $55 \mathrm{~d}$ after transplant (DAT), (B) marigold at $44 \mathrm{DAT},(\mathrm{C})$ pansy at $55 \mathrm{DAT}$, and (D) petunia at 44 DAT. Bars with the same lower case letters (within a species) are not significantly different according to paired comparisons (Tukey's honestly significant test with $P=0.05$ as a maximum value of significance). Substrate treatments consisted of $80 \%$ peat with $0 \%$ animal tissue compost [ATC (80P:0A)], $60 \%$ peat with $20 \%$ ATC (60P:20A), $40 \%$ peat with $40 \%$ ATC (40P:40A), $20 \%$ peat with $60 \%$ ATC (20P:60A), and $0 \%$ peat with $80 \%$ ATC $(0 \mathrm{P}: 80 \mathrm{~A}) .1 \mathrm{~cm}=0.3937$ inch.

Considerable variation in $\mathrm{pH}$, nitrogen, phosphorus, potassium, calcium, and iron content has been observed. The laboratory analysis of the ATC used in the present study (Table 1) indicated an EC of $8.05 \mathrm{mS} \cdot \mathrm{cm}^{-1}$, which is much greater than the recommended range of 0.7 to 3.5 $\mathrm{mS} \cdot \mathrm{cm}^{-1}$ for substrate (Dole and Wilkins, 2005). Above $5 \mathrm{mS} \cdot \mathrm{cm}^{-1}$, plants are expected to exhibit burn. Significant salinity in the ATC may be a result of using horse bedding as the only compost amendment (primary carbon source). Moreno-Caselles et al. (2002) reported that the EC in horse manure ranged from 3.50 to $13.6 \mathrm{dS} \cdot \mathrm{cm}^{-1}$, and expressed concern about its use as a soil amendment. Additionally, ATC may have had greater salinity because rumen contents contain considerable amounts of salt. Mayberry et al. (2010) used $\mathrm{EC}$ and the concentrations of $\mathrm{Na}$ and $\mathrm{K}$ in the rumen fluid as measures of rumen salinity in sheep fed diets containing differing amounts of salt. The EC of sheep given no salt supplementation and fed only a mixed ration of mostly wheat (Triticum sp.) coproducts, barley (Hordeum vulgare), oats (Avena sativa), and lupin (Lupinus sp.) was $14.1 \mathrm{mS} \cdot \mathrm{cm}^{-1}$. Rumen content $\mathrm{Na}$ and $\mathrm{Cl}$ were 2305 and 837 $\mathrm{mg} \cdot \mathrm{L}^{-1}$, respectively. When provided salt in the diet, EC of rumen contents increased to as great as $24.7 \mathrm{mS} \cdot \mathrm{cm}^{-1}$. Consequently, compost made with rumen contents may also have high salinity. The EC of 9-month-old rumen content compost has been reported to be $7.0 \mathrm{mS} \cdot \mathrm{cm}^{-1}$ (Shrestha et al., 2011). However, in that study, an uncovered composting system was used allowing for the exposure of compost to rain which contributes to the leaching of salts. For this study, the ATC was covered throughout the composting process, contained within a concrete bin with a sloped (inward) floor for total containment of all effluent within the compost. Consequently, this may be a third reason for the significant EC in the ATC, as there was no loss of salts during composting.

Some investigators have concerns with ATC having transmissible spongiform encephalopathies (TSE), which are a group of fatal neurodegenerative 

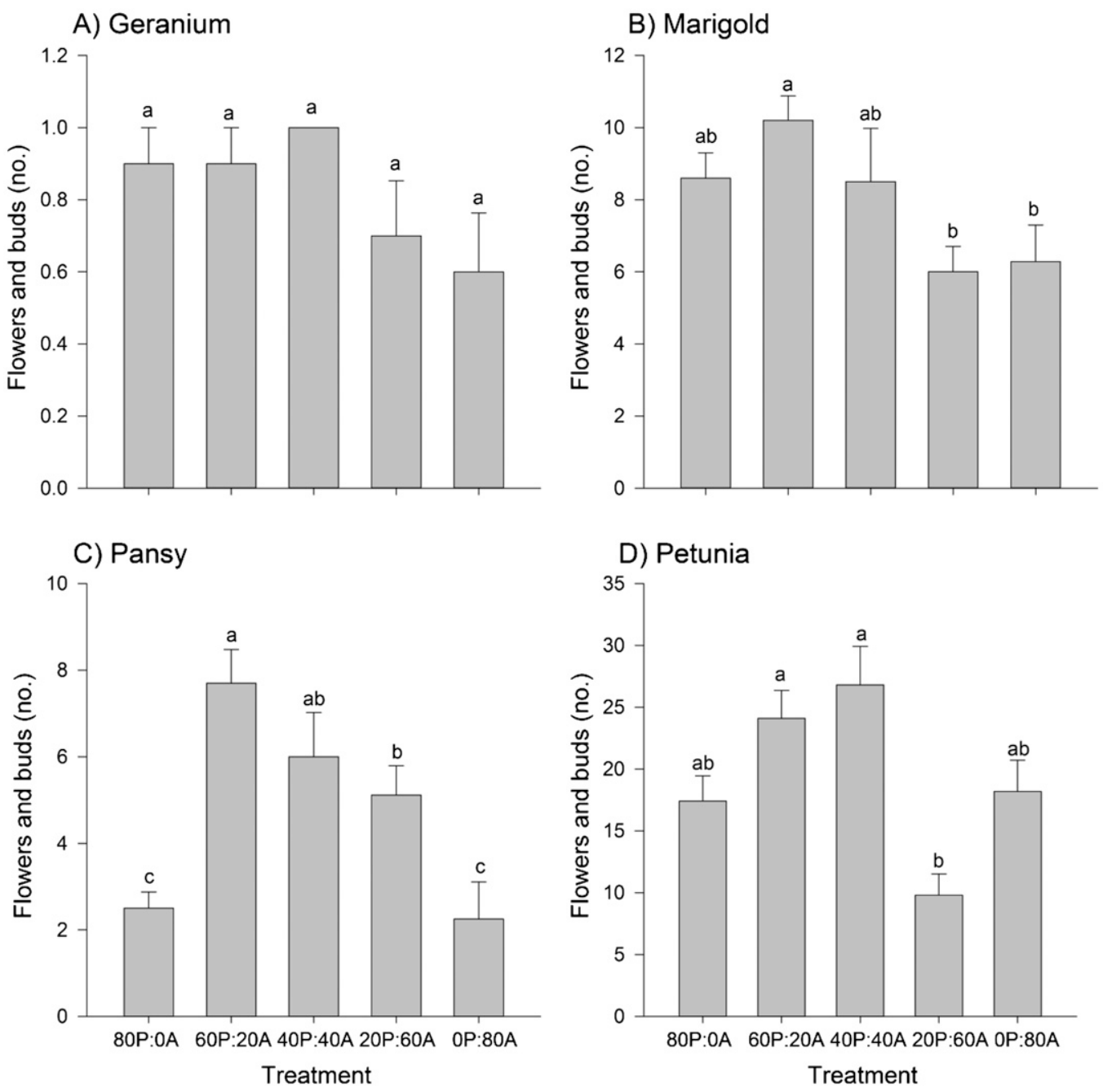

Fig. 4. Number of flowers and buds (with SE), excluding dead plants, for (A) geranium at $55 \mathrm{~d}$ after transplant (DAT), (B) marigold at $44 \mathrm{DAT}$, (C) pansy at $55 \mathrm{DAT}$, and (D) petunia at $44 \mathrm{DAT}$. Bars with the same lower case letters (within a species) are not significantly different according to paired comparisons (Tukey's honestly significant test with $P=0.05$ as a maximum value of significance). Bars with no SE are due to identical measurements across all subjects. Substrate treatments consisted of $80 \%$ peat with $0 \%$ animal tissue compost [ATC $(80 \mathrm{P}: 0 \mathrm{~A})$ ], $60 \%$ peat with $20 \%$ ATC $(60 \mathrm{P}: 20 \mathrm{~A}), 40 \%$ peat with $40 \%$ ATC (40P:40A), $20 \%$ peat with 60\% ATC (20P:60A), and 0\% peat with $80 \%$ ATC (0P:80A).

diseases that include scrapie in sheep and bovine spongiform encephalopathy (BSE) in cattle. The occurrence of these diseases involves changes in prion proteins in certain tissues [ specified risk materials (SRMs)]. The incidence of these diseases is extremely low in the United States (Center for Food Security and Public Health, 2008). In our project, bovine tissue was from young calves that had not consumed any feed products of animal origin. The sheep flock from which adult sheep carcasses would have originated has been involved in a scrapie eradication program for many years, and the potential for that TSE in mortality from that farm is considered extremely low. In the past 2 years, research by the Alberta government and the University of Alberta (Xu et al., 2013, 2014) has shown a $90 \%$ or greater degradation of SRMs (scrapie, BSE, and chronic wasting disease prions) after $28 \mathrm{~d}$ of active, properly managed composting. Because a very, very low risk of infection by ingestion still exists, our project proposes to use ATC as a potting medium for flowers and not for fruits, vegetables, or crops for animal consumption. However, growers should wear gloves when handling ATC.

SuRvival ANALYSIS AND HEALTH RATINGS. Geranium (Fig. 1A) and petunia (Fig. 1D) exhibited 100\% survival at the end of the study [at flowering, $55 \mathrm{~d}$ after transplant (DAT) for geranium and $44 \mathrm{DAT}$ for petunia].
Marigold (Fig. 1B) and pansy (Fig. 1C) had varying degrees of survival, depending on the treatment. The control treatment with no ATC (80P:0A) and the treatment with the smallest amount of ATC (60P:20A) showed 100\% survival for both species. Treatments for pansy and marigold with more than $40 \%$ ATC exhibited $40 \%$ to $90 \%$ survival.

Geranium (Fig. 2A), pansy (Fig. 2C), and petunia (Fig. 2D) all exhibited nearly perfect plant health scores across all treatments at the end of the study (55 DAT for geranium and pansy and 44 DAT for petunia), although pansy and petunia with the highest amount of ATC [80\% (0P:80A)] had a final score of 4.5. Marigold health ratings differed by treatment (Fig. 2B). The 

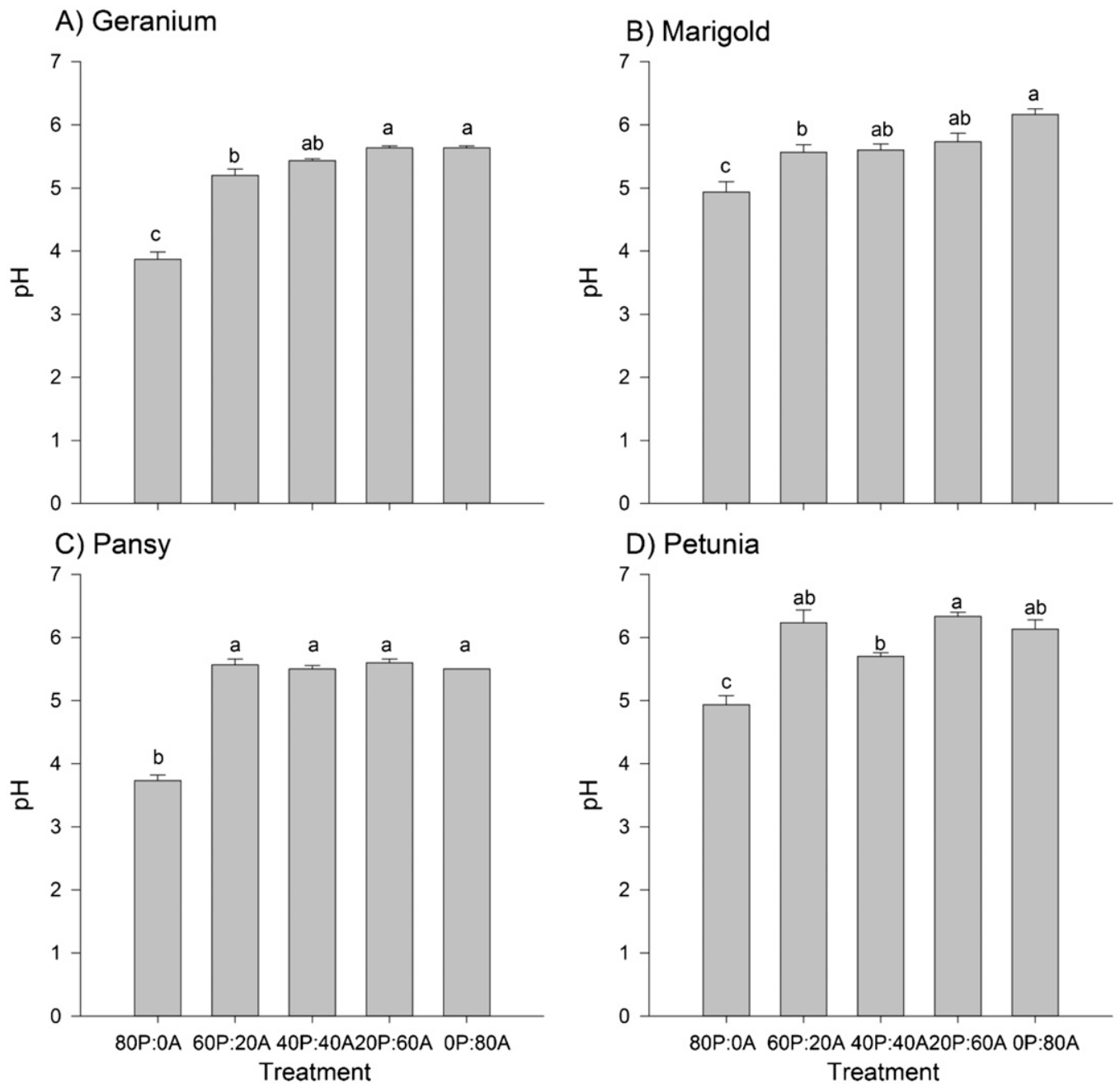

Fig. 5. pH readings (with SE) $44 \mathrm{~d}$ after transplant (DAT) by substrate treatment using the PourThru method (Whipker et al., 2001 ) for (A) geranium, (B) marigold, (C) pansy, and (D) petunia. Bars with the same lower case letters (within a species) are not significantly different according to paired comparisons (Tukey's honestly significant test with $P=0.05$ as a maximum value of significance). Bars with no SE are due to identical measurements across all subjects. Substrate treatments consisted of $80 \%$ peat with $0 \%$ animal tissue compost [ATC (80P:0A)], 60\% peat with 20\% ATC (60P:20A), 40\% peat with 40\% ATC (40P:40A), 20\% peat with 60\% ATC (20P:60A), and 0\% peat with 80\% ATC (0P:80A).

control with no ATC (80P:0A) and the treatment with the smallest amount of ATC (60P:20A) exhibited nearly perfect ratings at the end of the study (44 DAT). The other three treatments (any treatment with more than $20 \%$ ATC) had scores of 4.5 or less that made the plants unsuitable for sale. These plants had symptoms of a root or crown rot, twisted leaves, and necrotic leaf spots, which may have been due to inappropriate $\mathrm{pH}$ or $\mathrm{EC}$, discussed later.

GI AND NUMBER OF FLOWERS AND BUDS. For geranium and petunia [which had nearly perfect health ratings (Fig. 2A and D)], treatments that contained any amount of ATC had GIs equal to or greater than the control [80P:0A (Fig. 3A and D)] at the end of the study (55 DAT for geranium and 44 DAT for petunia). For marigold and pansy, in most cases, the ATC treatments had GIs equal to or lower than the control [80P:0A (Fig. 3B and C)]. Substrates consisting of more than $40 \%$ ATC for marigold and 60\% ATC for pansy are undesirable as plant growth suffered.

All ATC substrate treatments produced the same number of flowers and buds as the control (80P:0A) in geranium (Fig. 4A), marigold (Fig. $4 \mathrm{~B}$ ), and petunia (Fig. 4D) at the end of the study (55 DAT for geranium and 44 DAT for petunia and marigold). For pansy (Fig. 4C), the treatments containing $20 \%$ to $60 \%$ of ATC (60P:20A, 40P:40A, and 20P:60A) exhibited more flowers and buds than the control. The treatment with the highest amount of ATC (0P:80A) had the same number of flowers and buds as the control.

PH AND EC READINGS. The $\mathrm{pH}$ of the substrate impacts the availability of nutrients and thus plant growth (Dole and Wilkins, 2005; Peterson, 1982). For geranium, the ideal $\mathrm{pH}$ should range between 5.6 and 6.0 (Dole and Wilkins, 2005). If the $\mathrm{pH}$ falls below that range for geraniums, they may exhibit iron or manganese toxicity symptoms (Lee et al., 1996; Smith et al., 2004). All treatments except the control (80P:0A with a $\mathrm{pH}$ of 3.8) were in the appropriate $\mathrm{pH}$ range at 44 DAT (Fig. 5A). The control exhibited a low $\mathrm{pH}$ likely because lime was not applied to any treatment to adjust the $\mathrm{pH}$ of the substrates at any time before or during the study. Adding a lime material 

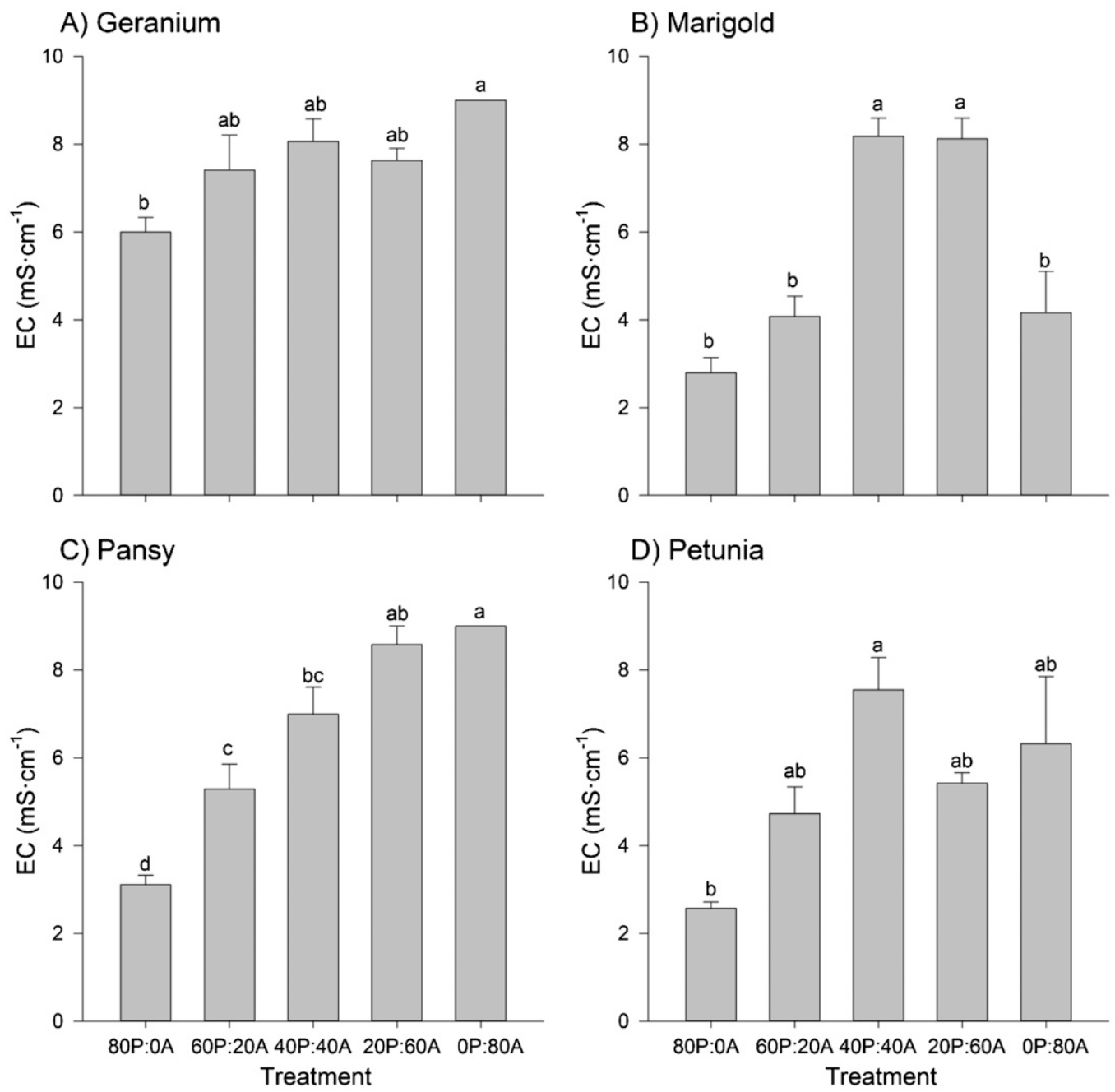

Fig. 6. Electrical conductivity (EC) readings (with SE) $44 \mathrm{~d}$ after transplant (DAT) by substrate treatment using the PourThru method (Whipker et al., 2001) for (A) geranium, (B) marigold, (C) pansy, and (D) petunia. Bars with the same lower case letters (within a species) are not significantly different according to paired comparisons (Tukey's honestly significant test with $P=0.05$ as a maximum value of significance). Bars with no SE are due to identical measurements across all subjects. Substrate treatments consisted of $80 \%$ peat with $0 \%$ animal tissue compost [ATC (80P:0A)], $60 \%$ peat with $20 \%$ ATC $(60 \mathrm{P}: 20 \mathrm{~A}), 40 \%$ peat with $40 \%$ ATC (40P:40A), 20\% peat with $60 \%$ ATC $(20 \mathrm{P}: 60 \mathrm{~A})$, and $0 \%$ peat with $80 \%$ ATC $(0 \mathrm{P}: 80 \mathrm{~A}) ; 1 \mathrm{mS} \cdot \mathrm{cm}^{-1}=1 \mathrm{mmho} / \mathrm{cm}$.

to a peat-based substrate is a common practice in production settings to increase substrate $\mathrm{pH}$ to an appropriate range for the species being grown (Argo and Biernbaum, 1996; Nelson, 2003). Even so, geranium in the control substrate (80P:0A) showed no symptoms of iron or manganese toxicity as described by Lee et al. (1996).

For petunia, substrate $\mathrm{pH}$ ranges should be between 5.0 and 6.0 (Dole and Wilkins, 2005). Petunia grown in a substrate $\mathrm{pH}$ above 6.0 can develop iron deficiencies, which did happen very slightly with the two substrates with the highest ATC amounts (20P:60A and 0P:80A), but only enough to show a slight dip in health ratings (Figs. 5D and 2D). For marigold, the $\mathrm{pH}$ should be between 5.8 and 6.8 and most treatments were close to that range (Fig. 5B). Even though the control treatment (80P:0A) exhibited a low $\mathrm{pH}$, the health ratings (Fig. 2B) were highest for that treatment.

For pansy, substrate $\mathrm{pH}$ readings should be between 5.5 and 6.0 (Dole and Wilkins, 2005). All the treatments containing ATC were in that range, while the control (80P:0A) was below that range but did not exhibit any signs of nutritional deficiencies or toxicities (Fig. 5C). However, as seen in Fig. 1C, pansy survival was minimal for the treatment with the highest amount of ATC (0P:80A) and the health ratings (Fig. 2C) were also the lowest for that treatment. One reason for this may be due to pansy being susceptible to root rot diseases with high substrate moisture (Mullen and Hagan, 2001). Pots containing substrate treatments with a high amount of ATC (like 0P:80A) were much heavier after irrigation than other treatments [i.e., wetter (personal observation)], which may allow root rot pathogens to develop on susceptible species. Although this hypothesis was not tested, the symptoms of the plants decline and death were consistent with the researcher's previous experience of root rot pathogens in pansy.

For mature plants, general PourThru EC readings should be between 2 and $6.5 \mathrm{mS} \cdot \mathrm{cm}^{-1}$ (Dole and Wilkins, 2005 ). The control (80P:0A) and the 
ATC treatment with the smallest amount of ATC (60P:20A) were generally within this range (Fig. 6). All other treatments exhibited an EC that was too high. However, the health and survival of geranium and petunia were not impacted by this (Figs. IA, $1 \mathrm{D}, 2 \mathrm{~A}$, and D2D). But, the high EC may explain the poor survival and health ratings for these substrates (0P:80A, 40P:40A, 20P:60A) for pansy (Fig. IC and $\mathrm{C}$ ) and marigold (Fig. IB and B). Symptoms of high EC include wilting (physiological drought), slow growth, necrotic leaf margins, and increased susceptibility to root rots (Dole and Wilkins, 2005). Marigold exhibited necrotic leaf margins as well as wilting in the treatments with high ATC (40P:40A, 20P:60A, and 0P:80A), which correspond to the high EC treatments (Figs. 2B and 6B).

\section{Conclusions}

On the basis of the species and the ratios of peat, ATC, and perlite tested here, ATC has the potential to be a peat extender in floriculture substrates when used in ratios of $20 \%$ or less. For all species, the ATC treatment with the lowest amount of ATC (60P:20A) performed nearly identical to the control (80P:0A) by all indices measured. Future research needs to explore alternative perlite concentrations to add aeration, which may allow more than $20 \%$ ATC as a peat extender. In addition, future research may be able to explore using less fertilizer to offset the ATC fertility inputs as well as determine if saltsensitive species [such as impatiens (Impatiens walleriana)] can be produced in ATC substrate. To market ATC to floriculture, a complete characterization of the compost purchased and blended into the substrate will be required. Because of varied nutritive attributes, including salinity, composting processes will need to be controlled to protect the environment and retain nutrients. From this study, we recognize that salts were retained in the compost (i.e., no leaching of salts due to precipitation occurred during the composting process). Animal tissue composting process management may consider using composting amendments with less nutrient concentration to produce compost with less fertility. Alternatively, ATC will need to be used at appropriate proportions in substrates as determined in this study.

\section{Literature cited}

Argo, W.R. and J.A. Biernbaum. 1996. The effect of lime, irrigation-water source, and water-soluble fertilizer on root-zone $\mathrm{pH}$, electrical conductivity, and macronutrient management of container root media with impatiens. J. Amer. Soc. Hort. Sci. 121:442-452.

Bilderback, T.E., W.C. Fonteno, and D.R. Johnson. 1982. Physical properties of media composed of peanut hulls, pine bark and peat moss and their effects on azalea growth. J. Amer. Soc. Hort. Sci. 107:522-525.

Center for Food Security and Public Health. 2008. Transmissible spongiform encephalopathies. 7 Oct. 2014. <http:// www.cfsph.iastate.edu/DiseaseInfo/ factsheets.php>.

Dole, J.M. and H.F. Wilkins. 2005. Floriculture: Principles and species. Pearson Prentice Hall, Upper Saddle River, NJ.

Evans, M.R. 2011. Physical properties of and plant growth in peat-based root substrates containing glass-based aggregate, perlite, and parboiled fresh rice hulls. HortTechnology 21:30-34.

Fulhage, C.D. 1994. Composting dead swine. Univ. Missouri Ext. Publ. Sheet WQ225, Water Quality Ser.

Gaches, W.G., G.B. Fain, D.J. Eakes, C.H. Gilliam, and J.L. Sibley. 2011. Comparison of aged and fresh WholeTree as a substrate component for production of greenhouse-grown annuals. J. Environ. Hort. 29:39-44.

Gizas, G., I. Tsirogiannis, M. Bakea, N. Mantzos, and D. Savvas. 2012. Impact of hydraulic characteristics of raw or composted posidonia residues, coir, and their mixtures with pumice on root aeration, water availability, and yield in a lettuce crop. HortScience 47:896-901.

Jackson, B.E. and W.C. Fonteno. 2013. New media components: Are they worth their weight in dirt? OFA Bul. 938:14-18.

Keener, H., D. Elwell, and J. Monnin. 2000. Procedures and equations for sizing structures and windrows for composting animal mortalities. Appl. Eng. Agr. 16:681-692.

Larcher, F. and V. Scariot. 2009. Assessment of partial peat substitutes for the production of camellia japonica. HortScience 44:312-316.

Lee, C.W., J. Choi, and C. Pak. 1996. Micronutrient toxicity in seed geranium (Pelargonium $\times$ hortorum Bailey). J. Amer. Soc. Hort. Sci. 121:77-82.
Mayberry, D., D. Masters, and P. Vercoe. 2010. Mineral metabolism of sheep fed saltbush or a formulated high-salt diet. Small Rumin. Res. 91:81-86.

Moreno-Caselles, J., R. Moral, M. PerezMurcia, A. Perez-Espinosa, and B. Rufete. 2002. Nutrient value of animal manures in front of environmental hazards. Commun. Soil Sci. Plant Anal. 33:3023-3032.

Mullen, J. and A. Hagan. 2001. Diseases of pansies and their control. Alabama Coop. Ext. Serv. ANR-1214:1-8.

Murphy, D.W. and T.S. Handwerker. 1988. Preliminary investigations of composting as a method of dead bird disposal. Proc. Natl. Poultry Waste Mgt. Symp. p. 65-72.

Murphy, A., C.H. Gilliam, G.B. Fain, H.A. Torbert, T.V. Gallagher, J.L. Sibley, and C.R. Boyer. 2011. Low-value trees as alternative substrates in greenhouse production of three annual species. J. Environ. Hort. 29:152-161.

Naddaf, O.A., I. Livieratos, A. Stamatakis, I. Tsirogiannis, G. Gizas, and D. Savvas. 2011. Hydraulic characteristics of composted pig manure, perlite, and mixtures of them, and their impact on cucumber grown on bags. Sci. Hort. 129:135-141.

Nektarios, P.A., S. Kastritsis, N. Ntoulas, and P. Tsiotsiopoulou. 2011. Substrate amendment effects on potted plant production and dry weight partition of Lantana camara. HortScience 46:864-869.

Nelson, P.V. 2003. Greenhouse operation and management. Prentice Hall, Upper Saddle River, NJ.

Peterson, J.C. 1982. Effects of $\mathrm{pH}$ upon nutrient availability in a commercial soilless root medium utilized for floral crop production. Ohio Agr. Res. Dev. Ctr. Res. Bul. 268.

Rozeboom, D.W. and D. Ross. 2014. Mortality compost nutrients and use on farm, ways to enhance nutrient content. Mortality Composting Conf. Amer. Inst. Goat Res. p. 15-20.

Rozeboom, D.W., J.G. Sirera, B.E. Straw, L.M. Granger, P.J. Fedorka-Cray, and B.J. Thacker. 1997. Disposing of swine carcasses and after-birth by composting. Final report to State of Michigan. File No. 19.42, ANS Mimeo No. 369.

Shober, A.L., C. Wiese, G.C. Denny, C.D. Stanley, and B.K. Harbaugh. 2010. Plant performance and nutrient losses during containerized bedding plant production using composted dairy manure solids as a peat substitute in substrate. HortScience 45:1516-1521.

Shober, A.L., C. Wiese, G.C. Denny, C.D. Stanley, and B.K. Harbaugh. 2011. 
Plant performance and nutrient losses during containerized landscape shrub production using composted dairy manure solids as a peat substitute in substrate. HortTechnology 21:240-245.

Shrestha, K., P. Shrestha, E.M. Adetutu, K.B. Walsh, K.M. Harrower, A.S. Ball, and D.J. Midmore. 2011. Changes in microbial and nutrient composition associated with rumen content compost incubation. Bioresource Technol. 102: 3848-3854.

Smith, B.R., P.R. Fisher, and W.R. Argo. 2004. Water-soluble fertilizer concentration and $\mathrm{pH}$ of a peat-based substrate affect growth, nutrient uptake, and chlorosis of container-grown seed geraniums. J. Plant Nutr. 27:497-524.
Stanford, K., V. Nelson, B. Sexton, T.A. McAllister, X. Hao, and F.J. Larney. 2007. Open-air windrows for winter disposal of frozen cattle mortalities: Effects of ambient temperature and mortality layering. Compost Sci. Util. 15:257-266.

Stanford, K., X. Hao, S. Hu, T.A. McAllister, F. Larney, and J.J. Leonard. 2009. Effects of age of cattle, turning technology and compost environment on disappearance of bone from mortality compost. Bioresource Technol. 100: 4417-4422.

U.S. Geological Survey. 2014. Mineral commodity summaries. 2 May 2014. <http://minerals.usgs.gov/minerals/ pubs/commodity/peat/mcs-2014peat.pdf $>$.

Whipker, B.E., T.J. Cavins, and W.C. Fonteno. 2001. 1, 2, 3's of PourThru. 2 May 2014. <http://www.ces.ncsu.edu/ depts/hort/floriculture/Florex/ PourThru\%20Handout\%20123s.pdf>.

Xu, S., T. Reuter, B.H. Gilroyed, S. Dudas, C. Graham, N. Neumann, A. Balachandran, S. Czub, M. Belosevic, J.J. Leonard, and T.A. McAllister. 2013. Biodegradation of specified risk material and fate of scrapie prions in compost. J. Environ. Sci. Health Part A 48:26-36.

$\mathrm{Xu}$, S., T. Reuter, K. Stanford, and T.A. McAllister. 2014. Can composting solve specified risk material issues? Mortality Composting Conf. Amer. Inst. Goat Res. p. 4l-48. 